\title{
Charity and Commercial Success as Vectors of Asymmetry and Inequality: The Unconceptualised Elements of Development in Islamist Sudan during the First Republic
}

\author{
Raphaëlle Chevrillon-Guibert
}

\begin{abstract}
The Sudanese Islamist experiment is far from having put an end to the conflict-ridden history of the country, despite the South achieving independence in July 2011. However, a higher degree of regional integration outside the South was one of the stated aims of the Islamists when they came to power in 1989. This chapter will investigate the apparent paradox by exploring the experiments in development undertaken by Sudanese Islamists during their first republic (1989-2011) on the basis of the study of certain social practices they actively encouraged, namely evergetism and philanthropy. It is based on an analysis of the charitable practices carried out by the main traders in the Sudanese capital's principal market during the Islamist regime. The regionalmore specifically Darfurian — origin of most of these main traders makes it possible to compare what these practices produce in each different territory. The chapter shows that this encouragement, which is not part of any specific plan thought up by the Islamists, leads to different forms of development that vary depending on the local and human contexts in which the actors live, and also the way they conceive their roles within in the circles to which they belong. It then highlights how these variations produce extremely disparate and often conflict-ridden results, which ultimately pursue the asymmetric formation of the Sudanese state, prolonging a historical trajectory that has produced injustice and generated conflict (Figure 11.1).
\end{abstract}

\section{Introduction}

In Sudan, Islamists ${ }^{1}$ have been in power for over twenty-five years, and have left a lasting mark on the trajectory of the Sudanese state. Before them, only

1 In this contribution, I will not go into the details of the Sudanese state apparatus; suffice to say the Sudanese regime is far from monolithic and since the early 1990's has significantly

(C) RAPHAËLLE CHEVRILLON-GUIBERT, 2017 | DOI 10.1163/9789004349551_012

This is an open access chapter distributed under the terms of the prevailing CC-BY-NC license at the time of publication. 

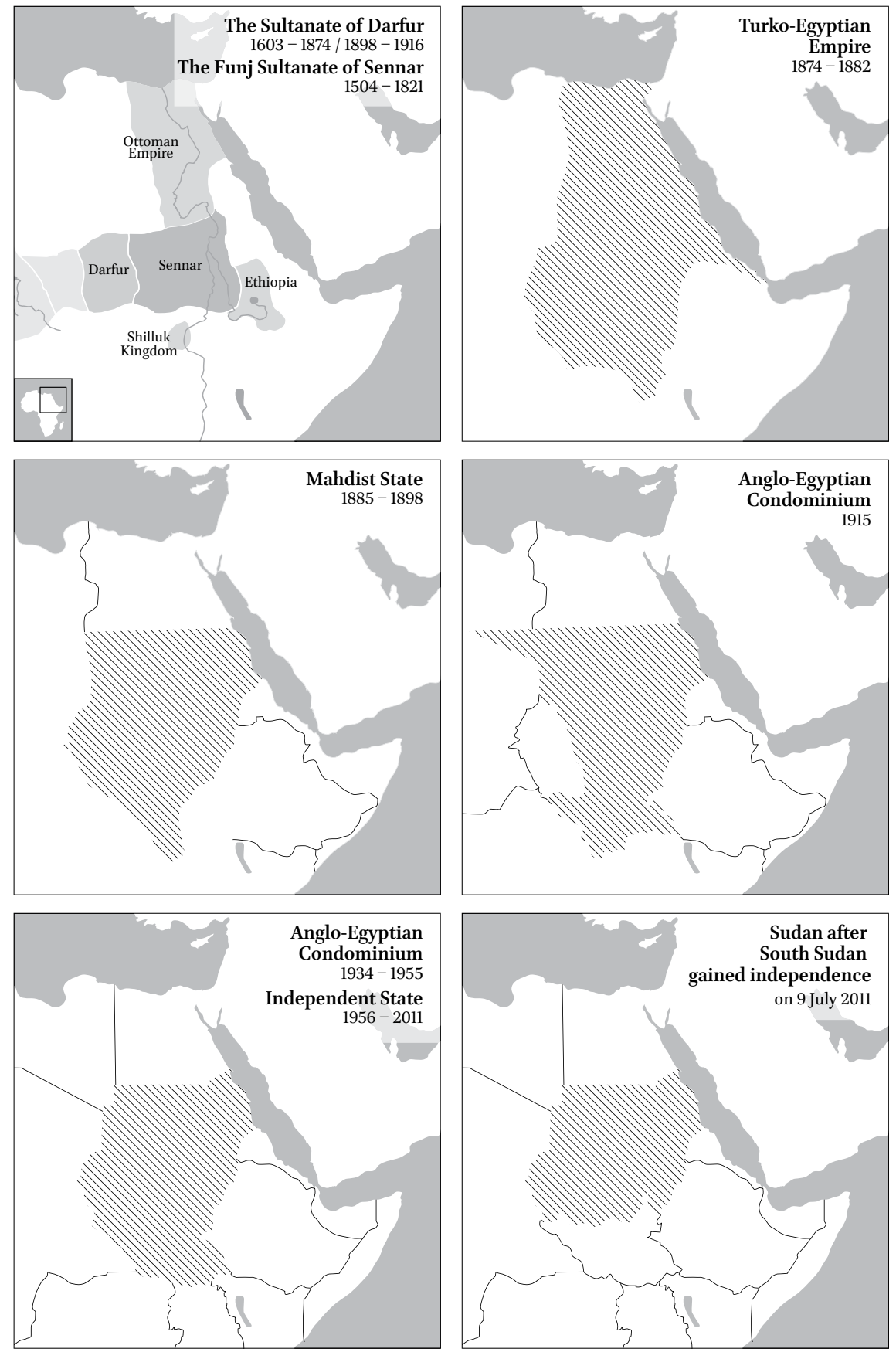

FIGURE 11.1 Map of Sudan and the evolution of its borders

SOURCE: ADAPTED FROM J. RYLE, J. WALLIS ET AL (EDS.) (2011), THE SUDAN HANDBOOK, (ROCHESTER: BOYDELL AND BREWER LTD), AND FROM A WIKIPEDIA ARTICLE HISTORY OF SUDAN. 
General Nimeiry managed to stay in power for more than a decade (from 1969 to 1985 ). In addition to their longevity, and though their political orientations seem quite different (Islamic and liberal on the one hand, secular and socialist on the other), both these regimes share a number of common characteristics: the authoritarian character of their political practices, of course, but also their explicit willingness to fundamentally transform Sudanese society and state and society relationships. Both have also rejected the colonial legacy of a Sudan where political and economic resources are concentrated in the country's centre, and both have been intensely hostile to the major traditional parties and their elites, which they accuse of having maintained this heritage, and the ethnicised power relations on which it was based, during the years they ruled the country.

The pursuit of colonial development based on agricultural export located in the central regions of the country by governments from the traditional parties has been widely noted (Roden, 1974; Bernal, 1997), as have the difficulties of the socialist regime to overcome this pattern of development (Niblock, 1987). In the late 1970 a real economic crisis faced the country, and these attempts were often judged hastily. Most importantly, the resumption of war in the South in 1983 and the dreadful famine that hit western regions in 1984 and 1985 have focused the attention of analysts; few studies have explored development policies by focusing on the actors who implemented them and how they are rooted in the specific local, regional, and international contexts (oil shocks, the massive levels of emigration of qualified Sudanese citizens to the Gulf States,

evolved. I use the terms 'Islamist regime' or 'Islamists' to describe the regime that took power in Khartoum in 1989, whose main pillar is the Islamic movement, i.e. the Muslim Brotherhood in Sudan, which became, under the leadership of Hassan al-Turabi, the Islamic Charter Front, then the National Islamic Front, and is now the National Congress Party. The generic term 'Islamic movement' is that used by Hassan al-Turabi, and it seeks to encompass more than just the political party, thus including not only the institutionalised aspect of the political activities of the movement, but also the satellite organisations. The term was taken up by Ali Osman Taha to designate the branch that refused to follow Turabi, who was ousted as a result of an internal schism in the movement in the late 1990s and who then created the Popular Congress Party (PCP); relatively active in the opposition to the regime, the PCP and its leader eventually renewed close informal links with the government during the period of the 'Arab Spring', mainly because of the international prestige enjoyed by Hassan al-Turabi, but also because of the exacerbation of internal rivalries within the Islamic movement over the succession of Omar al-Bashir. Another marked feature of the second republic (which began after the South achieved independence) lies in the important debates and confrontations to which it has given rise between religious political groups on issues relating to Islamic law (which form of sharia should be applied?). 
regional conflicts, and recurrent droughts in the Sahelian part of the country). ${ }^{2}$ The literature has mainly focused on the consequences of the crisis and developed a simplistic link between climate change and societal violence masking the long-term political-economic dynamics and the Sudanese political structure underpinning the crisis. ${ }^{3}$ Many studies have also investigated the health of the millions of Sudanese who have thronged to the suburbs of the capital to escape war or drought (Ibrahim and Ruppert, 1988); others have discussed food safety issues in rural areas (de Waal, 2005) or zones affected by conflict (Miller, 1993).

Even today, the literature on development in Sudan continues to pursue this line of analysis by exploring the problematics of the urbanisation of the capital and the modernisation of agriculture and livestock; the latter constituting the main livelihood for rural populations (Casciarri et al., 2015). ${ }^{4}$ Special attention is also paid to the form of education that Islamists have sought to encourage (Tenret, 2016). In general, development fostered by the Islamist regime's policy choices has not been addressed in terms of its inherently conflictual nature, as were the nationalisations of the Nimeiry regime. The exploitation of oil and minerals, livestock and grain production for export to specific regions, and the construction of large infrastructural projects, such as the dams on the Nile, are not choices that are questioned by the actors concerned, or discussed in the literature; ${ }^{5}$ rather, it is the profoundly unequal character of the regional distribution of these projects and of their principal beneficiaries that raises questions and objections. These inequalities have fomented all the opposition armed movements, whether in the South, Darfur, the East, or the regions of the Blue Nile and the Nuba Mountains. It is this aspect, too, that the literature addressing these conflicts favours; these studies detail this unequal distribution and the clientelism of the regime in developmental project selection and the allocation of public contracts. Recent studies complement these approaches by attempting to decipher what these development projects reveal about the practices of Islamist rulers and the way that the Islamist government works (Verhoeven, 2013; Beckedorf, 2012; Patey, 2014). The research on which my study is based follows the same path, shedding new light on the Islamists in

2 Apart, that is, from various studies by scholars such as R. Brown who analyzes in detail the attitude of international donors to the crisis in the Sudanese economy in the 1980s; see, especially, Brown (1989 and 1990).

3 On this issue see Verhoeven (2011) and also Brachet and Bonnecase (2013).

4 See also the work of the Feinstein International Center of Tufts University, http://fic.tufts .edu/research-item/sudan-environment-and-livelihoods/ (accessed on 29 April 2016).

5 With the notable exception of Gertel et al. (2014). 
Sudan. The literature on Sudanese political Islam focuses mainly on political actors, their thinking and discourses (studies including Woodward, 2013; Ibrahim, 1999), and on their relationships within the state apparatus (e.g. Gallab, 2016; Sørbø and Ahmed, 2013; Ahmed, 2007) and with the rest of the Sudanese political arena (Warburg, 2003). By studying the experiments in government carried out by Sudanese Islamists, this research seeks to understand what the latter make of power and what power makes of them.

The present study specifically aims to explore the experiment in development conducted by the Islamists during their first republic ${ }^{6}$ by investigating the social practices they have actively encouraged since coming to power: those of evergetism ${ }^{7}$ and social philanthropy. In 1989 , the value of the religious repertoire of redistributive generosity was systematically highlighted in the official discourse of the new regime. This was used both as a symbol of religiosity and as a tool of redistribution and development, along with its simultaneous institutionalisation, in particular through the obligatory payment of zakat.

By analysing how Islamists encourage redistribution practices, we can interpret their conception of development. In addition, deciphering how this appeal for generosity is variously received and translated by the governed, depending on the social roots and the sociopolitical context in which they move, should enables us to see, at least partially, how individuals and groups, each on their own scale, conceive development. How do they play a part in the production of development that varies according to groups and regions and the results of which sometimes prove paradoxical and often conflicting? How do these charitable practices combine with the development of the new entrepreneurial ethos promoted by Islamists? The answers to these questions should help us to envisage more complex configurations than expected and, in particular, show how the Islamist experience has gradually brought about a form of development that, in principle, is relatively consensual, but whose effects are widely conflicting because of the persistence of inequalities in the country's development.

To prove my point, I analyse the activities of the major markets of the Sudanese capital and the trajectories and practices of some of their actors mainly

6 The independence of South Sudan, which marked the beginning of the second republic, profoundly affected the regime and its economy, in particular causing the loss of most of the oil revenue that for several years had financed the regime's development projects. This led to the need for a major rethink.

7 I use the term 'evergetism' in Paul Veyne's sense: the financial investment of an individual for the public good, the gesture of 'a man who helps the community with his purse, a patron of public life' (Veyne 1976, 22); on the concept and its critics, see Andreau et al. (1978). 
during the first republic (until the independence of South Sudan in 2011). This analysis is based on empirical work carried out since 2004, mainly in the Sudanese capital, during which I have conducted more than 400 interviews in English and Arabic (with a translator) with traders and businessmen as well as many observations in the markets. ${ }^{8}$ My choice of the commercial sector is not insignificant. Although it represents only a small share of the gross domestic product (GDP), around 15 percent, this sector plays a central role in the Sudanese economic apparatus due to the low level of industrialisation of the country and the preponderance, since British colonisation, of agriculture and mining, which have become fundamental to the country's economy since the demise of the oil economy.

\section{Evergetism: A Specific Tool in Islamist Development}

In the very first months of their rule, the Islamists faced a severe food crisis in Darfur and Kordofan. The response to the crisis differed greatly from one region to another-in Kordofan, the governor declared a state of emergency that allowed him to obtain substantial international aid, while in Darfur, on the contrary, no state of emergency was declared and no outside help was received. This decision on the part of the governor of Darfur, a fervent Islamist, was fairly typical of the particular view that Islamists hold with regard to the role of the state and society: problems in medical care and food safety should be left to society through local NG Os (Miller, 1993). Darfuri people, especially its economic actors, were encouraged to create and finance such NGOS, ${ }^{9}$ while the regional authority focuses primarily on security issues..$^{10}$ We must also remember that the Islamists, and especially their leader Hassan al-Turabi, view international humanitarian organisations and their political, cultural and religious roles as vectors of the acculturation of Muslim populations (Bellion-Jourdan, 2006). This highly politicised vision of aid impels Islamists to fight actively against

8 Some of these observations and interviews were conducted as part of my doctoral research conducted between 2005 and 2013, for which I analysed the Islamist experience on the basis of the development of Darfuri Zaghawa communities (Chevrillon-Guibert, 2013a).

9 Various interviews, Khartoum, 2004-2012.

10 The region has suffered violent local conflicts since the late 1970s. In the late 1980s, a precarious peace was signed between the main groups involved, but the situation remains volatile in northern Darfur (Harir and Vedt (1994) and interview with Yusif Bakhit, secretary of the governor of Darfur between 1981 and 1985, then governor himself between 1986 and 1988, in Khartoum, April 2016). 
these international organisations, which they accuse of fostering a civilisation project that goes against their own, by limiting their interventions to a minimum. In 1991, Hassan al-Turabi went so far as to tell a Kuwaiti newspaper: 'Some want to use the decline in agricultural production caused by the drought to tie our hands. It is preferable for several thousand people to die rather than allow the international crusade to come to our aid. We will never proclaim that there is a famine while we are an Islamic nation (...) We will not allow international aid organisations to do what they want in our country and to oppose the plans of the Islamic Revolution in the South which, towards the end of 1991, will see the rebellion crushed.' (Sawt al-Kuwait, 25 March 1991, quoted in Bellion-Jourdan, 1997, 69).

By ascribing this role to aid organisations, Islamists were logically driven to create their own charitable organisations charged with spreading their vision of society. In 1980, even before they came to power, they set up the organisation known as Da'wa Islamiya (Islamic Call), whose initial objective was the spreading of Islam in Africa through education. The establishment of Da'wa Islamiya was supported by Mohammed al-Faisal, a director of the financial institution Dar al-Mal al-Islami and a main shareholder of the Faisal Islamic Bank created a year earlier. He was a personal friend of Turabi. The organisation also obtained the support of the Jami'at ad-da'wa al-islamiya based in Tripoli and the Muslim World League based in Jeddah. It was in 1981 that Da'wa Islamiya developed its own humanitarian arm, the Islamic African Relief Agency (IARA). ${ }^{11}$ At that time, these associations allowed Islamists not only to gain influence among the assisted populations but also to siphon off political support beyond their traditional sphere of influence thanks to the very positive response that they met with from all actors on the northern Sudanese political scene, which was dominated by religious parties. The context was at that time marked by the resumption of war in the South and by famine in the West, which drew many international humanitarian organisations into the country. However, the proximity of these associations to the Islamic movement came to be problematic, especially for secular parties, as it was very difficult to ignore their role in the development of Islamist ideology. ${ }^{12}$

Once they were in power, the Islamists maintained these organisations and encouraged the establishment of new ones, in particular granting them many

11 A few years later, the IARA became autonomous and the humanitarian activities of Da'wa Islamiya were taken over by two foundations 'Health' and 'Emergency' and the African Charitable Society for Mother and Child Care (Bellion-Jourdan, 2004).

12 In the South, these associations willingly favoured Muslim populations and also proposed Islamic alternatives to other communities (El-Affendi, 1990). 
tax exemptions. ${ }^{13}$ This shows that this initial decision was not only tactical, it reinforced the idea that Islamists pay special attention to charitable practices. The emphasis on encouraging generosity in a Muslim public is not in the least specific to Islamists. Nevertheless, the way the Islamists conceive of this generosity, and the centrality they give it, shapes the roles they attribute to the state and society (Marchal, 1999).

When the Islamists came to power in 1989 , they followed the Socialists twenty years before them by setting out to sustainably transform the country and its society. For the former, however, the implementation of 'good' development was not subject to a set pattern but needed to come from the 'good' actions of Islamised citizens. It was not a matter of setting up a new institutional structure or public policies designed explicitly to correct the inequities resulting from the accumulation of capital in a Sudan economically structured in favour of the central regions, but of turning each Sudanese citizen into a 'good' Muslim. ${ }^{14}$ The Islamist project is aimed primarily at fostering a new spirit in individuals; ${ }^{15}$ it focuses on devotion conceived both as an individual and as a social practice (Roy 1992). Therefore, the legitimacy of development implemented is linked to the legitimacy of the actors who promote it and to the legitimacy of their tools. This legitimacy should be primarily based on religion. As is clear from Turabi's aforementioned statement to the Kuwaiti newspaper, what counts is not so much the fate of potential beneficiaries as the Islamic project to which the donor contributes. ${ }^{16}$ Thus, Islamists do not seek to transform the mode of production of material life conditions as such, but rather consider that the inherent inequalities in society will be 'naturally' corrected by the Islamisation of societies and individual practices. If they are nonetheless convinced that the entire machinery of the economy must be conquered, this is primarily to secure their position in power, which will allow them to implement their project and find positions of influence for men, whose religious

13 Interviews, Khartoum, 2011.

14 Darfur has revealed that this priority was not shared by all and that most members of the peripheral regions were probably hoping for a much more active commitment on the part of the Islamist state to transform the inegalitarian dynamics of development in the country.

15 Reversals in the economic policies of the new regime also reflect battles within the regime between advocates of a liberal approach and those favouring a more statist line. The latter lost the first battle, with the appointment in 1990 of Abdel Rahim Hamdi, who for the next two decades would be the architect of the country's economic policies.

16 The creation of a Ministry of Planning with wide prerogatives, and the various activities in every sphere of Sudanese society, illustrate the Islamists' specific social strategy aimed at renewing Sudanese society on the basis of its individuals. 
faith will be the engine of change. The hesitations and debates within the Islamic movement as to the economic directions to be taken reflect this lack of a development model. ${ }^{17}$ The choices made in this area stemmed much more from the political agenda of Islamists seeking to stabilise the North, while continuing the war in the South, than they did from an ideological imperative or any logic of expertise to implement a specific development plan (Marchal and Ahmed, 2010). ${ }^{18}$

Redistribution practices are a typical example of operations promoted by the Islamist project, due to their individual and social character: by acting piously, the donor earns his or her salvation while signifying his belonging to the Islamic city that he or she is building. Charity thus becomes a tool for developing Islamic society, as illustrated by the institutionalisation of several old practices of evergetism such as paying the religious tax (zakat), ${ }^{19}$ which became mandatory in 1990, and whose base was also widened.

Logically, it is the generosity of those actors favoured by the regime that is primarily sought. Islamist militants donate up to 30 percent of their income to the movement. ${ }^{20}$ Economic actors who were close to the Islamists and have directly benefited from the largesse of the new government were also eagerly asked to act on behalf of the common good, ${ }^{21}$ as in the case of the Darfuri businessman Adam Yagoub, who-in Khartoum in the 1990s-chaired the very exclusive club that brought together the 25 most powerful Sudanese entrepreneurs. ${ }^{22}$ Adam was particularly generous to, and especially in Darfur, his native region, where he also started his business career, but he also funded the Sudanese state while executing — for instance - certain government contracts for the Army. ${ }^{23}$

17 On the role played by charitable donors in social integration, see the discussion (in a different context— the end of the Roman Empire) in Brown (2002); see also Ben Néfissa et al. (2005).

18 On this aspect, see Tozy and Hibou (2015) and Singer (2008).

19 This tax was introduced at the behest of Islamists in 1984 but was at that time a purely voluntary measure, intended to be imposed only on wealthy Muslims, for an amount that generally corresponded to 2.5 percent of their annual income.

20 Interviews with former members of the movement, Khartoum, 2015.

21 Interviews, Khartoum, 2004-2012; see also the episode of a government tour of the markets of the capital, as related by Baillard and Haenni (1997).

22 I analyse his career in Chevrillon-Guibert (2013b).

23 The list of his benefactions can be found in his official biography, published by his family after his death (Adam Yagoub Haroun, 2003); interviews with one of Adam Yagoub Haroun's sons, Khartoum, 2008, 2011 and 2015. 
It is easy to understand the conjunction of interests that entrepreneurs glimpse at this point, with the state appealing to their generosity in the context of practices of 'discharge' (Hibou, 1999) and their own economic interests: in exchange for their donations, these businessmen hope to obtain various benefits in return. This was particularly true in the 1990s when the government decided to privatise most large public companies; today one finds a similar dynamic in the allocation of licences for exploration and mining, an activity for which the state is responsible (Chevrillon-Guibert, 2016b). On the side of the state, one can easily imagine the mutual interest of such action as a tool to develop clientelism, and also to control prosperous individuals whose allegiance can be tested. Like the voluntary donations towards the regime's projects, the proper payment of zakat becomes an open sesame for developing one's business in Islamist Sudan, not only because it reflects the Islamic ethos of the entrepreneur, but also because it indicates his or her financial allegiance to the regime. And this allegiance was essential for the Islamist regime especially in the early years when it was actually fighting to survive, as its ability to provide a basic standard of living for the population was limited by an economy in crisis and the government was not yet in full control of all the machinery of state. Thus, the participation of society in public affairs did not lead to a withdrawal of the state but rather to its redeployment, since it was exercising greater control over economic actors and there was an extremely high level of permeability between society and state.

The promotion of the Islamic repertoire of values in the new form of government did not prevent a certain prevarication, in a classic pattern whereby state resources were appropriated by those actors in the system who were in positions of power (board members and administrative and/or political authorities). Soon, in addition to being the tool of generosity - as 'generous' entrepreneurs sought to win favours from the government—zakat also became a means of enrichment for several members of the state hierarchy who directly benefited from its funds (Muna Abdalla, 2008). Through citizen participation, development has thus become a political arena in which support is sought and also tested.

Major businessmen have never been, and are still not, the only people to be asked to contribute. All economic actors are invited to fund the civil and military operations of the state, whether this involves social philanthropy or financial tribute. ${ }^{24}$ Thus in Khartoum, where the bulk of the country's resources 
are concentrated, ${ }^{25}$ traders are encouraged to set up local charities, in the regions $^{26}$ and also in the capital, and to participate in state projects. On this last point, I should point out the long list of requests that have been and are being made to traders in the different markets of Khartoum. A letter sent, in 2002, by traders from the Libya souk, one of the largest markets in the Sudanese capital, lists the major contributions made by these traders to the community. ${ }^{27}$ It begins by citing all the market's infrastructure (including official buildings) and then mentions SDP 50,000 (USD 38 ooo) donated to the Sudanese army in 1984; several donations between 1995 and 1996 for the development of Sudanese security; a billion SDD (USD 13 millions) in 1997 to support the army and SDD 500 million in 2000 (USD 1,94 million) for the development of Muslim culture: ${ }^{28}$ to buy food for the mujahid - the name given to members of the Popular Defence Forces (PDF) fighting in the South in the name of jihad—and to fund mass weddings. It also mentions, without giving any amount, the financial support provided for the establishment of a camp for the PDF. This list shows that, in

25 Since independence, Khartoum has grown at a rate well above that of other Sudanese cities due to the centralisation of Sudanese politics and the unequal distribution of resources. Indeed, in 1990, the conurbation was home to 73 percent of domestic industry, 85 percent of commercial businesses in the country, 80 percent of banking services, 85 percent of bank loans to industry and 71 percent of those made with regard to real estate, 70 percent of taxpayers, and 80 percent of contributions. The decentralisation on which the Islamists embarked has not reduced the widening gap between the economy of Greater Khartoum and that of other regions, any more than has the oil economy that developed in the early years of the new millennium, even though that economy accounted for up to 7 percent of GDP and nearly 6o percent of the national government's resources in 2008 . Indeed, although the oil deposits are located in the regions, most of the economic benefits are concentrated in the capital and have generated only a very small profit for the oil-producing regions. The economic recovery that began in 2012 might change this division of wealth to some slight degree by involving the regions of the north and the east, and that between the two Niles where newly promoted agricultural and mining projects are located.

26 While all of the very powerful Darfuri business figures I have met, or their entourages (Adam Yagoub, Adam Daossa, and Siddiq Wada, to mention only the most famous), have founded charities to promote the development of Darfur and their native regions in particular, the same is also true of many smaller traders, who have joined colleagues from the same village or the same community to found charities for the development of their villages or to assist members of their communities. Interviews, Khartoum, 2008 and 2011.

27 The letter can be found in the appendix of my doctoral thesis (Chevrillon-Guibert, 2013a).

281000 SDP (Sudanese first pound $)=100$ SDD (Sudanese Dinar $)=1$ SDG (Sudanese second and third pound). Historical data of exchange rates can be found on the website of the Sudanese Central Bank. Data can also be found in the Master thesis of Mussabal (2008). 
addition to being encouraged to actively participate in the local development of their market by directly financing certain works, traders have also been ordered to mobilise for the nation. Just as the rest of the population was involved in the conscription of young people into the PDF, it was also expected to play an active part in the regime's war effort against the South, as it was investing in the establishment of those paramilitary forces in charge of protecting the regime. A similar pattern exists today with the Rapid Support Forces (RSF): these were created from the former Janjaweed militia and assist the PDF.

The enactment of the Popular Defence Forces Act in 1989 was part of the same context, as it established a paramilitary force whose objective was cooperation with the armed forces and the regular security services, but also the promotion, among Sudanese citizens, of a 'level of security consciousness' (Mohamed Salih, 2005, 8). The public sphere, then, was not viewed as the responsibility of a particular sector of the populace (administrators and politicians) but rather as every person in the country, combined: they were all called upon to be aware of their role. Again, the request for popular participation to establish a paramilitary security force was not specific to the Islamist regime, since the PDF were created by the Sadiq al-Mahdi government in 1986 to counter the militia of the Islamic movement, but also, and above all, to fight the Sudan People's Liberation Army in the South. However, here too the change lay in the growing importance of the PDF in the 199os compared to that of the regular armed forces (El-Battahani, 2016a). M.A. Mohamed Salih believes that by 1996 their number exceeded that of the armed forces and in 1999 it was three times higher (80,00o regular soldiers, 3,500 Islamist militants appointed as military officers, and 150,000 PDF) (Mohamed Salih, 2005, 9). The participation of the populace was encouraged by a religious rhetoric calling upon those drafted to wage jihad in the 'godless areas' of the South. Nevertheless, we must not lose sight of the material interests also involved in this process: the PDF provided the regime with protection against any attempted coup ${ }^{29}$ and the availability of inexpensive soldiers; for individuals who signed up, it meant an income, or at least a recognised position in society. Thus, both conviction and

29 Their effectiveness was demonstrated during the attack carried out by the Justice and Equality Movement on the capital in May 2008. It was the PDF and the national security forces (not the regular troops) that defended the city. Even now, the threat of an attack on Khartoum by the front representing the armed opposition leads the government to regularly deploy the PDF (now strengthened by rapid support forces created from the former Janjaweed militia) in all the districts and strategic locations in the city (Observations, 2013-16). This was also true during the major events of June 2012 and September 2013. The PDF took the lead in combats in which the loyalty of the military could not be counted on. 
material interests dictated the actions of the different groups involved and it is still the case today with RSF (El-Battahani, 2016b).

This active participation of citizens in public affairs, which includes their charitable activities, reflects a gradual withdrawal of the state in favour of active elements working on the revolutionary project. In the episode of the famine in Darfur in 1991 and 1992, for example, one cannot say that the Darfuri state was insensitive to the tragedies afflicting its people or that it held itself aloof from development issues. Rather, it was omnipresent and omnipotent, through the mechanisms of 'discharge'. The citizens of this Islamist state were now deemed responsible and ordered to create charities and to finance the city, including its buildings in the public space (mosques, roads, special public institutions, etc.) and its services (urban roads, hospital services and security services). These practices, then, do not point to a 'failure' of the state in Sudan or its 'weakness', but reflect instead a form of government that, to some extent, strengthens the state. The high level of porosity between the state and society promoted by such a form of government is not without consequences for the forms taken by development in Sudan: the state coffers were empty in the first decade of Islamist Sudan, and so the major development projects of the 1990s were based on these redistributive practices, made possible by the direct involvement of citizens who were now the architects of development, whether this was voluntary or obligatory. The manner in which individuals participated in this redistribution thus proved central to the way development was created, and clearly shaped it in all its aspects.

On the side of the ruled, how has this summons to generosity been heard and translated into practical terms? How can we evaluate the potential transformations furthered by this form of government?

One could certainly question the nature of the generosity of the ruled, assessing the 'success' or 'failure' of the Islamist project on the basis of the stated intentions of the actors concerned. It could then be explained in one of two alternative ways: by looking at their convictions, whether religious or ethical, or at their material interests. This type of reasoning would suggest that the social philanthropy of the traders seems to be motivated more by their nonmaterial and ideational interests (religious faith or community culture) while their evergetic practices - that is to say, their donations in favour of public life, are based on material interests (gaining a higher social status). Yet the reality is much more complex if we step back from the intentions and justifications 
claimed by the actors or attributed to them. We can gauge it only if we take into account the 'constellation of interests' in which their charitable practices are deployed. ${ }^{30}$

Take the example of the Darfuri traders from the great Libya souk; traders who flourished in the early years of Islamist domination. There was a significant demand for their support from members of their community, both those who had remained in Darfur, and were terribly impoverished by the conflicts and droughts that had lasted decades, and those who had migrated to Khartoum and needed to be taken care of, especially on arrival. The welcome offered by these wealthy individuals already settled in Khartoum was critical for Darfuris who were arriving in the capital even more impoverished than they might have been, as the roads between Khartoum and Darfur are long and expensive, making round trips between their villages and the capital few and far between.

The Libya souk, with its high level of development and preponderance of Darfuri traders from the Zaghawa communities, turned into an 'airlock' of integration for migrants from this community, who have consistently found jobs there. ${ }^{31}$ These migrants have certainly been a burden for the traders, but they have also been a boon to them, providing a cheap and accountable workforce, in a political context where discretion and trust were the fundamental conditions for the exercise of activities that often took place outside the official channels of the economy. ${ }^{32}$ In addition, the migrants have managed to become representatives of the traders in distributing the market's products. If we focus only on these motivations, however many and varied they may be, we will fail to take into account the actual way in which the generosity of traders is connected to the interests of power. It is precisely this connection-between an incentive to give and to act for the good of the community, the pursuit of personal goals, and the ability to respond to and to appropriate the injunctions of those in power- that generates the sometimes unconceptualised and contradictory effects of development.

$30 \quad$ I have been inspired by Hibou (2011) here. She draws on Weber (1978), as interpreted by Dobry (2013).

31 Interviews (2004-11) with traders who arrived in Khartoum in the 1970s, 1980s and 1990s.

32 We should bear in mind that the strategy adopted by Islamists to gain power has involved investing in the official economic sector through Islamic finance, but also more 'informal' means, using foreign exchange and money transfer services' networks. Upon their assumption of power, they implemented a witch-hunt in this parallel economy so as to ensure that the gateway to power would not be reopened by others after them. 
In assessing these effects, let us look again at the traders in the Libya souk who flourished with the rise to power of the Islamists; this will help us to understand what their actual practices and their 'trajectories of accumulation' tell us about the experience of Islamist development. ${ }^{33}$ When it came to power in the early 199os, the Islamic movement sought to undermine the foundations of the hegemonic alliance built by the major traditional parties since the Independence of the country. In the commercial sector, this took concrete shape in the intimidation or arrest of members of these parties, but also in the systematic destruction of the established commercial bourgeoisie, even if this latter was not openly militant. In the eyes of the new regime, its dominant position in the economic field, and its sociological composition, led to suspicions that it was a potential source of support for traditional parties. The Islamists primarily targeted the major traders linked to these traditional parties, traders who had re-established their business activities during the democratic interlude that followed the fall of the Nimeiry regime. Thus, in the early years of the Islamist regime, most of them-if they were not arrested or did not lose everything due to the first economic measures taken against them - went into exile. In this sense, the Islamists had learned from the socialist experiment: a similar process had taken place at the very beginning of the Nimeiry regime under which all foreign companies had been forced to leave the country and the upper class faithful to the traditional parties had been generally repulsed (Niblock, 1987). Smaller Sudanese traders, who were not targeted by this witchhunt, found this an excellent opportunity to engage in new business. Therefore a rather similar process took place in the early 1990s when entrepreneurs close to the major traditional parties left the country. A report by the World Bank in 2000 states that in 1994 a total of 282.6 in every 100,000 people had been imprisoned and that, for 1997 alone, 374,110 Sudanese had sought asylum abroad (World Development Indicators, quoted in Suleiman, 2007, 2).

The vacuum created by the expulsion of the traditional bourgeoisie did not benefit only those businessmen who were openly close to the regime. Other, less politicised entrepreneurs used their practical expertise to thrive in the space freed up by this process. In the capital, this greatly favoured the activities of the traders in the Libya souk, a popular market established in the late 1970s by Zaghawa Darfuri migrants and connected during its early years to the

33 We take this notion in the sense assigned by Geschiere and Konings (1993). It allows the authors to understand the historical variations in the possible modes of accumulation, which mean that, within the same country, there are various modes of accumulation shaping the relations between the State of Cameroon and the different regions of that country. 
border trade with Libya (Chevrillon-Guibert, 2016a). This market became, at the turn of the 1990s, the major market for the import of manufactured goods such as textiles, electrical appliances and hi-fi equipment. The sociological composition of the traders in the Libya souk, who came exclusively from the regions and not the major trading families in Khartoum, explains why they were not worried by the witch-hunt that followed the coming to power of the Islamists-especially as one of them, a fervent Zaghawa Islamist (this community is very active in the market), was chosen to oversee all the popular councils $^{34}$ in Umbadda, where the Libya souk is located. His intervention has enabled the market to develop. Public investments were made in infrastructure (a road serving the market, the construction of permanent shops, sanitation, etc.) and facilities were provided to the local popular councils to fund the traders' activities thanks to their role in the distribution of products subsidised by the regime. These committees tended to favour certain market traders.

This policy has been a success: in just a few years, the Libya souk has taken over from the historic markets of the city centre. Nevertheless, one has to wonder to what extent the traders in the Libya souk, who have found themselves favoured 'by default' by the new regime because of their non-politicisation, have actually been incorporated into these new hegemonic alliance built by the Islamists. It is crucial for our argumentation to answer this question, as it is the generosity of economic actors such as those of the Libya souk that has been sought by the Islamists to develop the country. So their actions constitute the core of the regime's development model.

In Darfur, we have seen that the refusal on the part of the regional state to call on Western aid, and the decision to encourage local mutual aid mechanisms, plus the extreme intensity of the relationship between the state and society, have led the precarious populations to rely on their family, clan and village networks - which all usually overlap. This configuration has also exacerbated the competition between groups for access to the local state and its scarce resources. The generosity of this new petty bourgeoisie has thus mainly taken the form of a community-based social philanthropy; other calls on their generosity from the regime, such as participating in public welfare, have been unwelcome, as they came on top of social obligations already considered

34 Popular councils (in Arabic: al-Lijan al-Sha'biyah meaning people's committee) are a central institution in the Islamist regime. They are the ultimate level of the federal system set up by the Islamists on their coming to power. Established on the model of the socialist popular committees of the socialist regime, they mainly play an intermediary role between the population and higher institutional levels. 
colossal. ${ }^{35}$ The scale of this community-based social philanthropy was further intensified by the withdrawal of the state from certain spheres, for example in terms of aid to cover the living costs of students, who had previously been receiving large government subsidies. Many traders began funding student accommodation for members of their families or people from their villages. But this entailed changes to community bonds, because, in regions like Darfur, belonging to a family or a village largely overlaps with belonging to one's ethnic group. While, under the previous regimes, students used to be mixed together upon their arrival at the state boarding schools of main towns or the capital, they now began to live almost exclusively with people of their own ethnic community. Thus, by discharging their obligations onto various actors in society whose businesses they had favoured, the Islamists in power unwittingly fostered new forms of community even as their project proclaimed that ethnic groups would disappear because 'Muslims don't know ethnic minorities' (Lowrie, 1993).

The structure of trade in the Libya souk has also promoted the formation of these new communal bonds insofar as the souk is a wholesale market sending goods to the regions; ${ }^{36}$ and the strengthening of links between the populations that had remained in Darfur and those who had left fostered the community spirit of the commercial networks. In Khartoum, a long-time business partner can easily be asked to host the relative of a trader who has settled in Darfur. Of course, these processes vary with the origins of the traders, because, although non-Darfuri market traders also have distribution networks in Darfur, they do not belong to the region, and thus the relationships forged in the pursuit of their economic activities do not follow community channels. Their professional relationships in Darfur are not based on the strong bonds of family or ethnic group (Granovetter, 1985). The development of their businesses in Khartoum, and their success, are part of the construction of very different trajectories from those of Darfuri traders: their paths are more independent and more in tune with the new shape taken by the old commercial bourgeoisie during the Islamist regime.

The situation of the Libya souk traders from the central regions, ${ }^{37}$ like that of the migrants from these regions, is very different from those of the Darfuris. While, throughout the 1990s, there have been an increasing number of

35 Interviews, Khartoum, 2008.

${ }_{3} 6$ Before the war, more than two-thirds of the products sold in the souk went to the markets of Darfur.

37 We define the 'central' regions as those of Khartoum, the north, the east, and the regions between the two Niles. 
conflicts in Darfur that have resulted in many human tragedies, the centre of the country has grown more stable and thus more profitable economically. This improved economic situation in the central regions and their proximity to the capital has thus led to trajectories different from those of people from Darfur. For the natives of central regions, integration into the capital is easier and is certainly less dependent on the help of members of the community already settled in Khartoum. People from these central regions who decide to strike out commercially in Khartoum generally start as itinerant traders, not as employees of a major trader from their community. ${ }^{38}$ In addition, those with the initial capital necessary to rent a shop usually have no preference with regard to the market in which they decide to settle; unlike Darfuri migrants who still systematically choose Omdurman, where members of their community live. ${ }^{39}$ Traders from the central regions who have settled in the capital were thus called upon to provide aid by members of their native villages far less often than were Darfuri traders, and this is still true today, as the war in Darfur continues. The regime's appeal to their generosity thus finds a very different response among those from the central regions. They willingly finance the development of the market where they work, or of the locality where they live in Khartoum, and they also invest personally by becoming members of various local councils. The links they maintain with their native region also assume a different shape from those of Darfuri traders insofar as the personal needs of inhabitants from Central regions are less than those of Darfur meaning that traders from Central regions would contribute to community development of their native area rather than personal fundings. Sometimes Darfuri traders also contribute to public welfare in Khartoum or in their region, but this usually occurs at a later stage, once the needs of those around them have been satisfied, or if they have significant capital at their disposal. They are therefore less likely than traders from the central regions to practise evergetism.

So, in the end, even when what is made in the way of donations is similar, charitable practices vary from one trader to another, as do their effects. Some gifts help maintain community relations that urban life would have tended to weaken, and that the Islamists had announced they planned to fight against, while others are evidence of involvement in the development of the Islamist city.

38 Various interviews in markets in Omdurman, al-Arabi, the Shaabi souk in Omdurman and Khartoum in November 2008.

39 The city of Omdurman, which was that of the Mahdi, retains a central place in the imaginaire of all Darfuris. Interviews, Khartoum, 2004-12. 
The war in Darfur, which broke out in 2003, reinforces this phenomenon. From the summer of 2004 onwards, many fund-raising drives have taken place in the Libya souk to assist the affected populations in the traders' native region..$^{40}$ The perpetuation of the conflict, which has now lasted for over ten years, increases even further the dependence of local populations vis-à-vis their compatriots living in other parts of the country, or abroad. In Khartoum, for example, all Darfuris are trying to help, in one way or another, the members of their community who are still in Darfur, most of whom now live in refugee camps. ${ }^{41}$ The destruction of villages, and life in the camps, make it impossible to carry out development projects similar to those financed by traders from the central areas in their native own villages.

This differentiation is also taking shape within regions, and between social groups. In Darfur, while the prosperity of some members of the Zaghawa communities has led to a high level of redistribution and encouraged the establishment of significant links of patronage, this is not the case for communities that have few business activities, whose members can count only on themselves. Without intermediaries, they look much more directly to the state, especially as, with the arrival of oil revenues in the early years of the new millennium, the state now has substantial resources at its disposal. These differentiated expectations created by the mechanisms of 'discharge' favour a high degree of asymmetry between social groups and thus make it possible to shed light on the decision taken by various Darfuri groups at the beginning of the war to join the state militias or, conversely, to opt for neutrality.

Other government initiatives, such as the creation from scratch of a civil administration (an-nizam al-ahli) in Khartoum based on ethnicity, handling only people from the western and southern regions, have also favoured this differentiation. This new administration is similar to that of the traditional administration of the regions (idarat al-ahlia), but its members are appointed by the regime. Like the popular committees, this new institution is responsible for encouraging participation in the rallies organised by the regime but also for national security, with individual contributions this time being sought via channels of ethnicity. If the government's goal is to more effectively control the population of Khartoum, where new Darfuris and southerners are constantly arriving, this policy mainly helps to fix individuals now living in Khartoum in their ethnicity, even as urban life and the gentrification of the local

40 Observations, Libya souk, Khartoum, 2004 and 2006; interviews, 2008-14.

41 Interviews, Khartoum, France and Juba, 2006-13. 
populations ${ }^{42}$ tend to weaken this same ethnicity. In Darfur, the recreation of a traditional administration has also tended to solidify identity by ethnicising the machinery of local political power in a devastated region. This hardening of identity boundaries has also been favoured by many administrative changes (Takana, 2008), which have tended to create mono-ethnic zones in previously ethnically mixed territories, gradually attaching the authority of traditional leaders to ethnicity and not, as previously, to region (Abdul-Jalil, 2015, 223-234).

In Khartoum, the regime also created, in the case of some communities, councils (shura) that brought together the elites of the same ethnic group, relying on their patronage to gain the favour of their community and, through their evergetism, making it possible for them to complete various projects without engaging the state financially. For Turabi, whose thinking largely shaped the policies implemented by the Islamists in the early years of the regime, the councils are the central institutions of this new Islamic state. They comprise the democratic Islamic alternative to Western democracy (Moussalli 1994, especially $57-63) \cdot{ }^{43}$ Shura (consultation) is supposed to allow the unification (tawhid) of all individuals by ensuring the development of a permanent consensus among the people in the framework of God's law (sharia). But creating these councils on an ethnic basis that includes many major traders promotes patronage, as it gives these traders a position of power, with the regime ensuring the personal allegiance of the members of the council by granting them favours. ${ }^{44}$ This process has given a communal flavour to the activities of this assembly, including the development projects it supervises.

Thus, the combination of different political factors and decisions (from the mechanisms of 'discharge' to the desire to control populations, from keeping Darfur in a state of underdevelopment to the increasing number of conflicts tearing the region apart), has resulted in the strengthening of ties between members of the same Darfuri ethnic, village and family communities in certain parts of the region, without this objective having been actively pursued by the authorities. This practice has, in concrete terms, brought closer together those trajectories that had tended to diverge in the 1980 , at the time of the

42 Unlike those of Darfur, the populations of Khartoum saw their living standards rise in the 1990s, and this favoured certain practices of consumption and a certain individualisation of success.

43 In this passage, Moussalli refers to Hassan Al-Turabi (1987a, 25-26; 1987b, 79-8o).

44 On the way peripheral elites are used and their allegiance is negotiated in return for payment and/or positions of accumulation, see de Waal (2007). For examples of shura, see Abdul-Jalil (2014) and Chevrillon-Guibert (2013a, 552 ff.). 
great migrations and the early years of the Islamic regime. Meanwhile, in Khartoum, it has limited the development of more horizontal links between people from different regions of Sudan-people sharing identical living conditions in markets such as the Libya souk, and has recreated a shared sense of destiny between populations that have remained in Darfur and those that have settled in the rest of the country or abroad.

Faced with the challenges that accompany the exercise of power, with the concessions and negotiations necessarily involved in day-to-day life, the construction of a new hegemonic alliance and development related to charitable practices promoted by the Islamists take unconceptualised and differentiated shapes, depending on the groups and regions involved. The difference is sharper between Darfuri traders and those from other regions because of the promotion by the Islamists of a particular entrepreneurial ethos - that of the modern, liberal entrepreneur who, while falling in with injunctions to generosity, also favours asymmetric and unequal development.

\section{The Entrepreneurial Ethos as a Factor of Exclusion}

During the early years of the regime, to benefit from the opening made possible by the Islamists' takeover and the 'organised bankruptcy' of the actors of the previous hegemonic alliance, new economic actors did not hesitate to move into the spheres of Islamist sociability. They did so particularly through the evergetic practices mentioned above, and, as we have seen in the Libya souk actors from the central regions have deployed more zeal in this task than their Darfuri colleagues have employed in supporting the populations of their bankrupt region. The gradual gentrification of these small-scale economic actors from the central regions reflects the gradual emergence of a new type of entrepreneur favoured by Islamists.

Before the petrodollars started coming in at the beginning of the new millennium, the launch of the 'salvation programme'-consisting of a series of reforms under the leadership of the new Minister of Finance and the Economy, Abdelrahim Hamdi- one of the founders of the Faysal Islamic Bank and a former London banker-fundamentally changed the rules of economic activity. The plan, then designed for a period of ten years, from 1992 to 2002, provided for a series of economic liberalisation measures and the privatisation of many public corporations. Such a programme would not have been unpopular with the economists of the International Monetary Fund (IMF), as the decision to reduce state spending and liberalise the economy was similar to the policies they themselves usually develop. The transition from a planned economy to 
a market economy in the context of a significant restriction of state budgets entailed a rearrangement of the positions of all the economic actors. Just as the seizure of power had provided the Islamists with new resources, shifted their interests, and changed their alliances, the new policies being followed again contributed to transformation.

In the trade sector, these economic developments went hand in hand with the commercial boom in Dubai, which led to a major reorganisation of the supply chain, and also of business practices. Egyptian and Libyan imports, where traders excelled, lost their competitiveness, and ease of trade with Dubai meant that the ability to endure harsh working conditions, as well as the control of several commercial channels, were no longer the great assets, in terms of achieving business success, they had once been. However, other qualities became more useful, such as having a permanent visa for Saudi Arabia or at least having contacts there; resources that individuals from the central regions of Sudan possess more frequently, since many of them have emigration experience of the Gulf. ${ }^{45}$ The profile of the successful entrepreneur was thus transformed.

The modernisation of professional practices carried out by the Islamists also led to significant changes. Legislation now required those seeking to carry out import activities to create trading companies, and several urban projects aimed to modernise the tangible practices of traders (shop fronts, the use of new technologies, etc.). These reforms were also designed to better control the sector, by combatting the opacity of commercial networks and the illegal practices that these networks' fluidity seems to facilitate. But this modernisation and the mastering of new codes of conduct and business practices require a basic minimum of education. Now, historically, education is an important marker of the difference between the old trading families of the central markets in the capital and entrepreneurs in the Libya souk who come from the regions and lower social strata. Wealth created by wholesale and import has made it possible to finance the education of the children of traders in the central markets. The fact that they settled earlier in the capital or in the major cities where educational institutions are more numerous than in Darfur (and also more numerous than in many central regions) also favoured this higher level of schooling. The new guidelines laid down by the Islamist regime therefore allowed the least politicised traders of the old bourgeoisie to go back into business, especially as many young entrepreneurs directly favoured by the Islamists in the early years of their regime had proven to be poor businessmen.

45 On the elites that emerged from the Islamist governmental experiment, see ChevrillonGuibert (2017). 
But in the late 199os, the Islamist movement was ready to accept businessmen who were less ideologically correct, but more successful financially, especially since the development of oil revenues provided members of the regime and their families with direct resources much more significant than those previously gained from levies on business activities. The development of trade with the Gulf also promoted this comeback of people in line with the old bourgeoisie because many young people who invested in the central souks had spent some years in the Gulf to build up their capital.

Within the Libya souk, non-Darfuri traders were (like traders from the El Arabi souk or Omdurman) better educated than their Darfuri counterparts, because although they were not from the capital they had generally been better educated in their native regions. ${ }^{46}$ The new global configuration of trade has accentuated both this advantage and the success enjoyed by these entrepreneurs. China's rise in the 1990s as a source of cheap supplies required significant capital, and it is the biggest non-Darfuri traders who had this capital. Similarly, it is they who control the machinery needed to trade with Chinasuch as the ability to travel in a new universe much stranger than the Arab Gulf countries, Egypt or Libya had been-and a knowledge of new technologies such as the internet. The Arabic language is no longer of any particular use, as English is becoming an indispensable asset and is conferred by a good education. The local context is also proving very unfavourable to Darfuri traders: the war in Darfur is increasing the constraints on their ability to distribute goods, and the regime's distrust of them (it suspects them of supporting armed groups) is also a hindrance to their activities.

Thus, in the Libya souk, the profile of the entrepreneurs emerging in the late 1990 is similar to that of the old bourgeoisie of the central souks: educated, coming from the central regions, and also more individualistic. With them, community ties have loosened and aspirations are becoming more individualistic. Future plans primarily concern the individual and his nuclear family (wife, children) ${ }^{47}$ and are part of the national community. These traders, we have seen, regularly invest part of their profits in politics, or at least in the public sphere. They are also active in those organisations that manage the activities

46 These observations were made by several Darfuri entrepreneurs who had been to university and noted the discrepancy between the level of education of Darfuri traders in the souk and that of traders from other regions (Khartoum interviews, 2014). Darfur has always been the Sudanese region with the lowest level of education, though there are big differences between different regions and different populations (see in particular the report 'Literacy and Education' prepared by the Central Bureau of Statistics in Khartoum). Interviews, Khartoum, June 2015. 
of their market and, with age and reputation, they achieve a status that is local (on the scale of the municipality) and then national (across Khartoum State or possibly in their region of origin), in a rather traditional pattern of annexation and clientelism. The results of the 2010 general elections, ${ }^{48}$ which were very favourable to the regime, reflected the success of this scheme of development for the central regions, which saw the virtual disappearance of the major traditional parties in favour of the ruling party, the National Congress Party.

Meanwhile, the oil economy gave the regime new ways of achieving its modernising ambitions by allowing it to invest in modern, technological infrastructure. It was, yet again, the central regions that benefited from many projects during the 'oil decade': between 2001 and 2009, several large dams were built in the north, as well as 2,80o kilometres of paved roads extending from the capital to the north, the east, and the region between the two Niles, as against barely 300 kilometres in Darfur, even though it comprised one-fifth of Sudan before the separation of the South. This new infrastructure favours the economic development of these regions - which are, as an added advantage, at peace - and thus fosters the rising standard of living of their populations. Logically, traders from these regions benefit from this economic upturn, while in Darfur the lack of infrastructure and, in particular, the war greatly hampers trade and led to the impoverishment of the part of the population that is now in refugee camps.

The processes of differentiation and, in particular, the new modes of community life for some and the increase in individualisation for others have prevented the formation of a common destiny among the traders in the Libya souk. The policies implemented have reactivated the differentiated past lives led by everyone before they arrived in the market; similarly, the maintenance or-contrariwise - the abandonment by traders of the links that existed between them and the members of their communities who had remained in the regions appear to be factors of separation rather than reconciliation. It is also these historically constructed trajectories that shape the future plans of each group and their relationship to the world, in particular to the national community. While traders from the central regions tend to lose their original regional identity, this identity remains clearly marked and manifestly organises the specific social lives of Darfuri traders.

48 In the elections of 2015, largely boycotted by the opposition, there was no real political issue at stake. This was not the case for the elections of 2010, which-admittedly-were largely rigged, but which constituted the first test of power after the South had broken away, but also after the internal split among the Islamists in the late 1990s during which the leader of the movement, Hassan al-Turabi, was ousted. 
However, some features that are emerging among many Darfuri traders, particularly the Zaghawa, are not completely different from those of the new Islamist bourgeois elite. The Darfuri traders too have upgraded their professional practices and appreciate the benefits of a certain material modernity, but they are clearly very different from the bourgeois elite in the importance they place, in their social relationships, on strong bonds, often those of family. The existence of such bonds is, for many, the sine qua non of their economic success, and their relationship to the land and the state and hence to development. While the bourgeois elite strives for integration into and recognition in the national community, the framework of these much more mobile Darfuri traders is largely disconnected from the national territory. It is primarily their personal experiences and their native territory, as they imagine it through the collective memory of their ethnic community, which shape the contours of their own 'mental map' (Migdal, 2004, 9-10).

The new economic policies of the regime could further alter the situation: it is now the regime's task to remedy the loss of the oil economy, concomitant with the breakaway of the South in 2011, by encouraging investment in agriculture and mining. It is true that these new economic development policies largely reflect the framework of the old ones by fostering the modernisation of these sectors (through the promotion of industrialisation in the mining sector and the rationalisation of the commercial livestock sector), which encourages, yet again, a certain kind of entrepreneur. Similarly, the concentration of administrative procedures and business activities in Khartoum in the case of the mining sector (Chevrillon-Guibert 2016b), and in certain specific areas all located in the central regions in the case of the livestock sector, ${ }^{49}$ reinforces a very unequal development that favours the country's capital and certain regions. However, the fact that these two sectors are largely dependent on activities in the regions, some of which are on the periphery, may alleviate this inequality, which has generated highly unbalanced regional development. The way in which activities, whether involving mineral extraction or agriculture, are conducted as well as the conflicts they generate locally promote the redeployment of regional strategies for investors who themselves usually remain in Khartoum. ${ }^{50}$ The asymmetry that the new policies perpetuate thus leads, in parallel, to a redefinition of relations with the regions, although the profoundly unequal structure of the Islamist development experiment is not explicitly challenged by the new development projects envisaged by the government. 
The development experiment set up by the Islamists during their first decades in power does not fall into a predetermined, explicit pattern that their political opponents might have challenged before it was implemented. The specificity of their experiment does not lie, either, in the kind of neo-liberal development that they are advancing, as this neo-liberal thinking now seems widely shared by the entire political class. The tools of development count much more than its results. Thus, when it comes to development, Islamists first encourage practices they consider 'islamically' good because they are the ones which are legitimate in their eyes. The form taken by this development, and its concrete results once applied, which sometimes conflict with the political project of the Islamic movement, take second place; they count in the political agenda of power but are not part of the civilisation project in which the movement is engaged.

Charitable practices have naturally been part of the Islamic repertoire promoted by the Islamist project and, logically, it is economic actors who have mainly been asked to contribute. As no specific development blueprint has been provided for them, these actors display their charity in different ways, according to the local and human contexts in which they live, but also in accordance with the particular ways they conceive their roles in the circles to which they belong (family and ethnic, local and national communities). This participation in development, sometimes engaged in under duress, involves many changes, not only in the forms taken by development and in its scale (which is dependent on the donors' capacities) but also in the spaces concerned (regions, capital, urban and rural zones) and in the groups that benefit. Such variations necessarily produce highly disparate and often conflicting results, sinceultimately - some recipients initially targeted by the government have been excluded and the regional inequalities inherited from previous experiences are maintained and even accentuated. The same process still subsists today, yet the legitimacy of development is not really discussed because it is based on practices deemed to be legitimate. The oil economy of the early twenty-first century however, has completely reshuffled the cards, profoundly reorganising the balance of power between the state and society: during this period, the regime has not only claimed religious legitimacy, that of the Islamic revolution, but above all a modernising legitimacy, that of the developmental state (Jones et al., 2013). In the latter model, the rulers justify their position of power by their ability to transform the economy and by the material benefits that result. This transformation favours conflicts around development because it places the results, and not the tools, at the heart of the debates on its legitimacy. The 
glaring inequalities feed deep frustration and a sense of injustice among those excluded from development, especially since this oil wealth could have helped to proactively remedy these inequalities. The regime, however, has preferred to consolidate its base among the populations of the capital and the central regions and to ignore the inequalities at the heart of the conflicts that are now tearing the country apart, as was the case for the South. Thus, far from pursuing any original trajectory, this Islamic state seems rather to be pursuing a path of 'asymmetric formation, ${ }^{51}$ in line with its historical trajectory-a trajectory that has produced injustice and long been a source of conflict.

\section{References}

Abdalla, Muna A. (2008) Poverty and Inequality in Urban Sudan: Policies, Institutions and Governance, African Studies Collection, 13 (Leiden: African Studies Center), http://hdl.handle.net/1887/13106 (accessed on 22 June 2016).

Abdul-Jalil, Musa A. (2015) 'From native administration to native system: the reproduction of a colonial model of governance in post-independence Sudan', in A.M. Assal and M.A. Abdul-Jalil (eds.) Past, Present, and Future. Fifty Years of Anthropology in Sudan (Bergen: Chr. Michelsen Institute).

Abdul-Jalil, Musa A. (2014) Retribalisation of the Educated Elite in Darfur and the Phenomenon of Tribal Shura Councils; with a Special Reference to the Fur Shura Council, CMI Sudan Working Paper SWP, 5, 22 p., http://www.cmi.no/publications/5316-re tribalisation-of-the-educated-elite-in-darfur (accessed on 20 June 2016).

Adam Yagoub Haroun (2003) The traits of the life of a religious, Adam Yagoub Haroun (Khartoum: private publishing house, in Arabic).

Ahmed, E. (2007) 'Political Islam in Sudan. Islamists and the Challenge of Power (19892004)', in B.F. Soares and R. Otayek (eds.) Islam and Muslim Politics in Africa (New York: Palgrave Macmillan).

Al-Turabi, Hassan (1987a), Qadaya al-huriyya wa al-wahda wa al-shura wa aldimucratiyya [Issues of Freedom, Unity, Shura and Democracy] (Jeddah: Al-Dar al-Su'udiya li al-Nashr waal-Tawzi').

Al-Turabi, Hassan (1987b), Tajdid al-fikr al-islami [The Renewal of Islamic Thought] (Jeddah: Al-Dar al-Su'udiya li al-Nashr waal-Tawzi').

$5^{1} \quad$ This analysis, based on asymmetry and differentiation, owes much to the work of Béatrice Hibou in this area, especially her chapter 'La formation asymétrique de l'État en Tunisie. Les territoires de l'injustice', in Bono et al. (2015). 
Andreau, J., A. Schnapp and P. Schmitt (1978) 'Paul Veyne et l'évergétisme (note critique)', Annales, 33(2), pp. 307-325.

Baillard I. and P. Haenni (1997) 'Libéralité prétorienne et État minimum au Soudan', Égypte/Monde arabe, 32, pp. 71-96, http://ema.revues.org/1671 (accessed on 22 June 2016).

Beckedorf, A.-S. (2012) Political waters. Governmental water management and neoliberal reforms in Khartoum/Sudan (Berlin: Lit Verlag).

Bellion-Jourdan, J. (2006) 'Les ONG islamiques sont-elles vraiment humanitaires ? Réflexions sur une vraie fausse question', Vacarme, 34, http://www.vacarme.org/ar ticle558.html (consulté le 18 décembre 2015).

Bellion-Jourdan, J. (2004) 'Réseaux transnationaux de l'aide humanitaire islamique : les ONG islamiques', in S. Ben Néfissa et al (eds.), ONG et gouvernance dans le Monde arabe (Paris : Khartala and CEDEJ), pp. 113-142.

Bellion-Jourdan, J. (1997) 'L'humanitaire et l'islamisme soudanais-Les organisations Da'wa Islamiya et Islamic African Relief Agency', Politique Africaine, 66, pp. 61-73, http://www.politique-africaine.com/numeros/pdf/o66o61.pdf (accessed on 2o June 2016).

Ben Néfissa, S., N. Abdelfattah, C. Hanafi S. Milani, (eds.) (2005) NGOs and governance in the Arab world (Cairo: American University in Cairo Press).

Bernal, V. (1997) 'Colonial Moral Economy and the Discipline of Development: The Gezira Scheme and Modern Sudan', Cultural Anthropology, 12(4), pp. 1-33, DOI: 10.1525/can.1997.12.4.447.

Bono, I., B. Hibou, H. Meddeb and M. Tozy (2015) L'État d'injustice au Maghreb. Maroc et Tunisie (Paris: Karthala).

Brachet, J. and V. Bonnecase (2013) 'Les « crises sahéliennes » entre perceptions locales et gestions internationales', Politique africaine, 130(2), pp. 5-22, DOI : 10.3917/ polaf.130.0005.

Brown, P. (2002) Poverty and Leadership in the Later Roman Empire (Hanover: University Press of New England).

Brown, R. (1990) The IMF and Paris Club Debt Rescheduling: A Conflicting Role? ISS Working Paper, 30 (The Hague: Institute of Social Studies).

Brown, R. (1989) 'The Rationale and Effects of the IMF Stabilisation Programme in Sudan', in B. Campbell (ed.), Political Dimensions of Third World Debt (London: Macmillan), pp. 51-91.

Casciarri, B., A.M. Assal and F. Ireton (eds.) (2015) Multidimensional Change in Sudan 1989-2011. Reshaping livelihoods, conflicts and identities (Oxford and New York: Berghahn).

Chevrillon-Guibert, R. (2017) 'Importing goods to Khartoum: traders between Sudan, China and Dubai', in U. Röschenthaler and A. Jedlowski (eds.) Mobility Between 
Africa, Asia and Latin America: Economic Networks and Cultural Interactions (London: Zed Books).

Chevrillon-Guibert, R. (2016a) 'Les commerçants zaghawa du Darfour (Soudan) : des passeurs de frontières', Territoire en Mouvement, 29, http://tem.revues.org/3303 (accessed on 2o June 2016).

Chevrillon-Guibert, R. (2016b) 'Le Boom de l'or au Soudan', International Development Policy 7.2, DOI : 10.4000/poldev.2231.

Chevrillon-Guibert, R. (2013a) Des commerçants au cour de l'expérience islamiste au Soudan. Rapports de/au pouvoir et recompositions des communautés darfouriennes zaghawa à l'aune des alliances du mouvement islamique soudanais (1950-2011), $\mathrm{PhD}$ thesis, (Clermont-Ferrand: Université d'Auvergne), http://www.fasopo.org/sites/de fault/files/jr/th_chevrillon-guibert.pdf (accessed on 20 December 2015).

Chevrillon-Guibert, R. (2013b) 'La Guerre au Darfour au prisme des alliances du mouvement islamique. Retour sur quelques trajectoires d'hommes d'affaires zaghawa', Politique africaine, 130(2), pp. 113-136, DOI : 10.3917/polaf.130.0113.

de Waal, A. (2007) 'Sudan: What kind of state? What kind of crisis?', CSRC Occasional Paper, 2, LSE, April, http://www2.lse.ac.uk/internationalDevelopment/research/ crisisStates/download/op/op2DeWaal.pdf (accessed on 20 June 2016).

de Waal, A. (2005) Famine that Kills. Darfur, Sudan (Oxford: Oxford University Press, Oxford-1st edn 1989).

Dobry, M. (2013) 'Légitimité et calcul rationnel. Remarques sur quelques complications de la sociologie de Max Weber', in P. Favre, J.E.S. Hayward and Y. Shemeil, Etre gouverné: études en l'honneur de Jean Leca (Paris: Presses de la FNSP), pp. 127-150.

El-Affendi, Abdelwahab (1990) “Discovering the South": Sudanese Dilemmas for Islam in Africa', African Affairs, 89(356), pp. 371-389, http://www.jstor.org/stable/722373.

El-Battahani, Atta (2016a) 'Civil-Military Relations in Sudan: Negotiating Political Transition in a Turbulent Economy' in E. Grawert and Zeinab Abul-Magd (eds.), Businessmen in Arms. How the Military and Other Armed Groups Profit in the MENA Region (Lanham: Rowman \& Littlefield Publishers).

El-Battahani, Atta (2016b) The Sudan Armed Forces and Prospects of Change, CMI Insight vol. 4, (Bergen: Chr. Michelsen).

Gallab, Abdullahi A. (2016) Their Second Republic: Islamism in the Sudan from Disintegration to Oblivion (New York: Routledge).

Gertel, J., R. Rottenburg and S. Calkins (eds.) (2014) Disrupting Territories. Land, commodification and conflict in rural Sudan (London: James Currey).

Geschiere, P. and P. Konings (1993) Itinéraires d'accumulation au Cameroun (Paris: Karthala).

Granovetter, M. (1985) 'Economic Action and Social Structure: The Problem of Embeddedness', American Journal of Sociology, 91(3), http://www.jstor.org/stable/ 2780199 . 
Harir, Sharif and T. Vedt, (eds.) (1994) Short-Cut to Decay (Uppsala: Nordiska Afrikainstitutet).

Hibou, B. (2011) Anatomie politique de la domination (Paris: La Découverte). English translation forthcoming (2017), The Political Anatomy of Domination (London: Palgrave).

Hibou, B. (1999) 'La décharge, nouvel interventionnisme?', Politique africaine, 73(1), pp. 6-15, DOI: 10.3917/polaf.073.00o6.

Ibrahim, A.A. (1999) 'A Theology of Modernity: Hassan al-Turabi and Islamic Renewal in Sudan', Africa Today, 46(3/4), pp. 195-222, DOI: 10.1353/at.2003.0094.

Ibrahim, F. and H. Ruppert (eds.) (1988) Rural urban migration and identity change. Case studies from the Sudan, Bayreuther geowissenschaftliche Arbeiten, 11 (Bayreuth: Druckhaus Bayreuth).

Jones, J., B. Soares and H. Verhoeven (2013) Africa's illiberal state-builders, RSC Working Paper Series 89 (Oxford: University of Oxford), https://www.rsc.ox.ac.uk/files/ publications/working-paper-series/wp89-africas-illiberal-state-builders-2013.pdf (accessed on 23 June 2016).

Lowrie, A. (1993) Islam, Democracy, the State and the West: A Round table with Dr. Hasan Turabi, World and Islam Studies Enterprise (Florida: Tampa), pp. 35-36.

Marchal, R. (1999) 'Des contresens possibles à la globalisation. Privatisation de l'État et bienfaisance au Soudan et au Somaliland', Politique africaine, 73(1), pp. 68-81, DOI: 10.3917/polaf.073.0068.

Marchal, R. and Einas Ahmed (2010) 'The Multiple Uses of Neoliberalism: War, New Boundaries, and Reorganization of the Government in Sudan', in F. Guttiérrez and G. Shönwälder (eds.), Economic Liberalization and Political Violence: utopia or dystopia? (New York: Pluto Press).

Migdal, J.S. (2004) Boundaries and Belonging. State and Societies in the Struggle to Shape Identities and Local Practices (Cambridge: Cambridge University Press).

Miller, C. (1993) 'Famine, conflits et aide internationale au Darfour, 1990-1992', Égypte/ Monde arabe, first series 15-16, http://ema.revues.org/1017 (accessed on 24 August 2015).

Mohamed Salih, M.A. (2005) Understanding the Conflict in Darfur, Occasional Paper from the Centre of African Studies (Copenhagen: University of Copenhagen), $29 \mathrm{p}$. http://citeseerx.ist.psu.edu/viewdoc/download?doi=10.1.1.474.326o\&rep=rep1\&typ $\mathrm{e}=\mathrm{pdf}$ (accessed on 22 June 2016).

Moussalli, A.S. (1994) 'Hasan al-Turabi's Islamist Discourse on Democracy and Shura', Middle Eastern Studies, 30(1), pp. 52-63, DOI: 10.1080/00263209408700982.

Mussabal, Y.M.A. (2008) 'Export Promotion Policies in the Sudan for the period (19902005)', Master Thesis, University of Khartoum (mineo).

Niblock, T. (1987) Class and Power in Sudan-the dynamics of Sudanese Politics 18981985 (New York: State University of New York Press). 
Patey, L. (2014) The New Kings of Crude: China, India, and the Global Struggle for Oil in Sudan and South Sudan (London: Hurst).

Roden, D. (1974) 'Regional Inequality and Rebellion in the Sudan', Geographical Review, 64(4), pp. 498-516.

Roy, O. (1992) The Failure of Political Islam, trans. Carol Volk (Harvard, MA: Harvard University Press).

Singer, A. (ed.) (2008) Charity in Islamic Society (Cambridge: Cambridge University Press).

Sørbø, G. and A.G.M. Ahmed (eds.) (2013) Sudan Divided. Continuing Conflict in a Contested State (New York: Palgrave Macmillan).

Suleiman, Osman (2007) Current Privatization Policy in Sudan, Policy Brief 52 (Michigan: The William Institute, University of Michigan).

Takana, Youssef (2008) The Politics of Local Boundaries and Conflict in Sudan. The South Darfur Case, Sudan Working Paper 2008/2 (Bergen: Chr. Michelsen Institute).

Tenret, E. (2016) 'Exclusive Universities: Use and Misuse of Affirmative Action in Sudanese Higher Education', Comparative Education Review, 6o(2), pp. 375-402, DOI: $10.1086 / 685687$.

Tozy M. and B. Hibou (2015) 'L'offre islamiste de justice sociale. Politique publique ou question morale ?', in B. Hibou, I. Bono, M. Tozy and H. Meddeb, L'État d'injustice au Maghreb. Maroc et Tunisie (Paris: Karthala).

Verhoeven, H. (2013) 'The Rise and Fall of Sudan's Al-Ingaz Revolution: the Transition from Militarised Islamism to Economic Salvation and the Comprehensive Peace Agreement', Civil Wars, 15(2), pp. 118-140, DOI: 10.1080/13698249.2013.817846.

Verhoeven, H. (2011) 'Climate change, conflict and development in Sudan: global neoMalthusian narratives and local power struggles', Development and Change, 42(3), pp. 679-707, DOI: 10.1111/j.1467-7660.2011.01707.x.

Veyne, P. (1976) Le pain et le cirque. Sociologie historique d'un pluralisme politique (Paris: Le Seuil).

Warburg, G. (2003) Islam, Sectarianism and Politics in Sudan since the Mahdiyya (London: Hurst).

Weber, M. (1978) Economy and Society. An Outline of Interpretive Sociology, (Berkeley: University of California Press).

Woodward, P. (2013) 'Hasan Al-Turabi', in J.L. Esposito and E. El-Din Shahin (eds.) The Oxford Handbook of Islam and Politics (Oxford: Oxford University Press). 